No. 04-1

\title{
Economic Policy and Prospects in Iraq
}

\author{
Christopher Foote, William Block, Keith Crane, and Simon Gray
}

\begin{abstract}
:
This paper describes the Coalition Provisional Authority's attempts to stabilize and reform Iraq's economy along market lines. It argues that while security concerns remain serious, Iraq's economy has not been crippled by violence. However, sustained economic growth will depend on whether Iraq's future leaders pursue the pro-market approaches the Coalition has advocated. If the Iraqi economy is to reach its potential, it will need to go even farther than the Coalition did, implementing reforms the Coalition did not pursue because of security concerns.
\end{abstract}

Christopher Foote is a Senior Economist, Federal Reserve Bank of Boston, Boston, Massachusetts. William Block is an Economist, U.S. Department of the Treasury, Washington, D.C. Keith Crane is a Senior Economist, the RAND Corporation, Arlington, Virginia, office. Simon Gray is Adviser to the Governor, Bank of England, London, United Kingdom. All four of the authors worked at the Coalition Provisional Authority, Baghdad, Iraq. Their e-mail addresses are <chris.foote@bos.frb.org>, <blockw@orha.centcom.mil>, < Keith Crane@rand.org>, and $<$ Simon.Gray@bankofengland.co.uk>, respectively.

This paper is available on the web site of the Federal Reserve Bank of Boston at http://www.bos.frb.org/economic/ppdp/index.htm and is forthcoming in the Journal of Economic Perspectives, 2004.

The views expressed in this paper are solely those of the authors and do not reflect official positions of the Coalition Provisional Authority, the U.S. Treasury, the Bank of England, the U.S. Federal Reserve System, or any other national or international agency. Officials of the International Monetary Fund and World Bank participated in many of the discussions discussed in this paper. Though the number of people who worked with us and thereby contributed to this paper is far too large for us to name them all, we would like to note the particularly useful contributions of two persons: Scott Brown, the IMF's resident representative in Iraq, who was injured in the bombing of the Canal Hotel on August 19, 2003; and Jacob Nell, a senior adviser to Iraq's Ministry of Finance on leave from the British government, who was injured in the attack on the Al-Rasheed Hotel on October 26, 2003.

This version: May 4, 2004 
Economic reform was central to the Coalition Provisional Authority's attempts to rebuild Iraq. Coalition Administrator L. Paul Bremer made this clear in his first speech before the international community, delivered on June 23, 2003, before a special meeting of the World Economic Forum held in Amman, Jordan. Noting that "the first job of any government is to maintain law and order," Bremer began his talk with a pledge to confront the looters, saboteurs, and street criminals that plagued Iraq after the war. Bremer also noted that a governing council of Iraqis would soon be established to help manage the country. But most of Bremer's speech focused on what he called his "third and most immediate priority": rebuilding the economy.

Bremer described a state where more than 60 percent of the population depended on government food rations to survive. After achieving middle-income status in the late 1970s, Iraq's economy imploded during its war with Iran in the 1980s and the UN sanctions that followed the Persian Gulf War. The Iraqi government responded to the international sanctions by printing money to finance its operations, stoking inflation and debasing the currency. Other economic problems were strictly domestic in origin. The government controlled investment decisions through its control of oil revenues, propped up money-losing, state-owned enterprises and spent billions on wasteful consumer subsidies. Non-Arab foreign investment was prohibited, and the Baathist regime was extraordinarily corrupt. "Put simply," Bremer said, "Saddam Hussein's regime devastated Iraq's economy from the inside out."

This paper describes the Coalition's attempts to stabilize and reform Iraq's economy along market lines. It argues that while security concerns remain serious, Iraq's economy has not been crippled by violence. Since the end of the conflict, small businesses have been able to grow and thrive despite domestic unrest. A plurality of Iraqis believe that the employment situation in Iraq is better now than before the war. Unemployment remains high, however, and a large majority of Iraqis believe that improved job opportunities would reduce violence. Reconstruction spending will create jobs and raise incomes this year, but sustained economic growth will depend on 
whether Iraq's future leaders pursue the pro-market approaches that the Coalition has advocated. If the Iraqi economy is to reach its potential, it will need to go even farther than the Coalition did, implementing some reforms that the CPA did not pursue because of security concerns.

\section{Iraq's Economy Before the War}

Although Iraq's ruling Baath party was socialist, the country had a mixed economy before the war. Most people worked in the private sector, though a majority of these jobs were in the informal economy. Many were engaged in trading or subsistence agriculture or some other form of self-employment. Probably no more than a fifth of the labor force worked for regular pay in a formally registered firm. About a quarter to a third of the labor force worked for the government, mostly in a government ministry, the army, or in one of the 200 or so aging state-owned enterprises. The government did not set prices for private goods, but it controlled all oil revenues and the prices of refined oil products. It could force private firms to act in consort with the "national plan," and, after 1990, it directly distributed food rations to virtually everyone in the country.

Saddam Hussein created the food rationing system in response to a United Nations embargo imposed days after Iraq invaded Kuwait. The food basket was increased after 1996, when the UN's Oil-for-Food program allowed Iraq to sell oil in exchange for humanitarian imports. Iraqis were free to supplement their rations with purchases from the private market, but their ability to do so was limited by low incomes. Those at the bottom of the public-sector pay scale, like teachers, made less than $\$ 10$ per month before the 2003 war. Moving up the income distribution, a branch manager at a state-owned bank made about $\$ 40$ per month, and the owner of a private-sector food store in Baghdad might clear $\$ 60$ a month. The country's Minister of Oil had an annual base salary of $\$ 20,000$ (Oliver and McPherson, 2003). 


\section{GDP}

Reliable figures for aggregate income before the war do not exist. Saddam Hussein did not publish real GDP figures, and those that were calculated (and kept hidden) were distorted by valuing international transactions at the official exchange rate of 0.311 Iraqi dinars per U.S. dollar. By the late 1990s, inflation had caused the market rate of the dinar to depreciate to around 2,000 to the dollar.

Figure 1 presents our rough estimates for real per-capita GDP, based in part on data from Iraq's Central Statistical Organization (CSO)..$^{1}$ After 1991, the data do not include figures for the three northern Kurdish-dominated provinces, or "governorates." The Kurdish region became essentially autonomous after the Persian Gulf War, protected by a no-fly zone established by the allies.

During the 1970s both the oil and the non-oil sectors grew rapidly. World oil prices were high, and Iraq's oil production rose from 1.5 million barrels per day (bpd) in 1970 to 3.5 million bpd in 1979. Soaring oil revenues allowed the government to conduct investment programs outside the oil sector, so the non-oil economy grew as well.

Iraq's economic meltdown began with the onset of its eight-year war with Iran in September 1980. Oil production virtually ceased the following month, and Iraq's Gulf port facilities were destroyed in November. Production averaged slightly more than 1 million bpd from 1981 to 1985, recovering to just below 3 million bpd the year after the war. The second major interruption to oil revenues came during the Persian Gulf War. Allied attacks in January 1991 brought a complete halt to oil production; postwar exports were constrained by the ensuing UN embargo. Oil production was held near the level of domestic consumption (about 500,000 bpd) until 1996, at which point Iraq

\footnotetext{
${ }^{1}$ Data from Iraq's CSO can be used to figure non-oil GDP, because the use of inaccurate exchange rates does not distort the non-oil figures from the domestic economy nearly as much as those for the oil sector. Nominal, non-oil GDP is first deflated into 2002 dinars using Iraq's consumer price index. Dividing the resulting constant-dinar series by the 2002 exchange rate (1955.25 dinars $=1$ dollar) gives an estimate of real non-oil GDP in terms of 2002 U.S. dollars. Output in Iraq's oil sector is estimated from data from the U.S. Energy Information Agency (which closely track data from the Iraqi government during the period when the two sources overlap).
} 
agreed to the Oil-for-Food program. Both the oil and non-oil sectors recovered somewhat in the late 1990s, but remained severely depressed relative to the 1970s.

By 2001, GDP per capita at market exchange rates was about $\$ 960$ per year, with oil output accounting for more than two-thirds of that amount. Outside of the Kurdish region, Iraq had about 22 million people in 2001, so aggregate GDP was slightly more than $\$ 21$ billion.

These real GDP estimates are constructed with constant base-year prices, including oil export prices. They therefore abstract from the decline in the relative price of oil after $1980 .^{2}$ One way to assess the combined effects of price and quantity declines on Iraq's oil export revenues is to deflate current-dollar oil export earnings into 2002 dollars using the U.S. GDP deflator. This exercise reveals that in 2002 dollars, per capita export earnings declined from a high of more than $\$ 4,100$ in 1979 and 1980 to about $\$ 544$ in 2002 - a drop of more than 86 percent.

\section{Employment}

Data from Iraq's 1997 census can be used to generate labor-force participation rates and employment shares by industry. The results, which pertain only to civilian employees outside the Kurdish region, are displayed in Table 1. As of the census day (October 16, 1997), about two-thirds of Iraqi men aged 10 or older were in the labor force, though only 7.5 percent of women were. This rate of female participation is low even among economies of the Middle East. Although oil accounts for most of Iraq's GDP, it is extremely capital intensive, accounting for less than one percent of aggregate employment. The largest employers for men are public administration, wholesale and retail trade, and agriculture. For women, major employers are education and agriculture. Although women are less likely to be in the labor force, those who work are likely to be more highly educated than men, often working as teachers or government

\footnotetext{
2 Oil prices averaged about $\$ 37$ per barrel in 1980, falling to a low of $\$ 15$ during the 1986 price collapse and rising to around $\$ 15-\$ 20$ for most of the late 1980s and 1990s. Since 2000, oil prices have fluctuated generally around $\$ 30$ per barrel, reaching $\$ 40$ per barrel this spring.
} 
technocrats. Table 1 also shows that about 18 percent of men and 2 percent of women were unemployed when the survey was taken.

\section{Infrastructure and investment}

Even before the looting and sabotage of 2003, Iraq's infrastructure was fragile because of a dearth of capital investment during the previous two decades. Figure 2 presents real gross capital formation in the private and government sectors from 1980 to 2001. The data are unadjusted figures from Iraq's CSO, but because they measure domestic investment in real terms, they are less affected than the GDP figures by the overvaluation of the official exchange rate. The figure shows that both public and private investment collapsed during the Iran-Iraq war, and was miniscule during the 1990s.

Iraq's infrastructure also bears the scars of the 1990-91 Persian Gulf War. Allied attacks hit the country's electricity grid and telecommunications network particularly hard. According to a recent joint UN/World Bank assessment (2003a), peak electricity demand before the Gulf War had been about 5,000-7,500 megawatts (MW), and generating capacity had been about 9,300 MW. Damage from allied attacks during the Gulf War reduced generating capacity to just 2,300 MW.

During the 1990s, efforts to rebuild the infrastructure were thwarted by the UN embargo, which denied the country a source of spare parts. Iraqi engineers still managed to repair much of the electricity grid by cannibalizing parts from some generating facilities to rebuild others. Parts imported through the UN Oil-for-Food program permitted generating capacity to climb to about $4,400 \mathrm{MW}$ by 2002 . While generating capacity remained below demand throughout the 1990s, not all of Iraq suffered equally from power shortages. The government regularly channeled electricity to Baghdad at the expense of the much poorer southern part of the country, which had rebelled against the regime after the Gulf War.

The 1990s saw Iraq's stock of human capital stagnate along with its physical infrastructure. A comprehensive literacy campaign in the 1970s and 1980s had reduced 
illiteracy among 15-45 year olds from 48 percent in 1978 to 20 percent in 1987

(UN/World Bank, 2003b). In 1991, all literacy programs outside the formal school system ceased, as did new construction and maintenance of school buildings. By the time of the 2003 war, students were often going to school in double or triple shifts because of a lack of adequate buildings. According to the United Nations Human Development Report, 55 percent of Iraqis aged 15-24 were illiterate in 2001, by far the highest such rates in the Arab world.

\section{Government finance, debt and inflation}

When the Iran-Iraq war and the UN embargo disrupted oil sales, the government was denied its main source of income. Funds raised through internal taxation typically totaled less than 3 percent of GDP; income from state activities, such as wages earned in state-owned enterprises, was exempt from taxation. Small firms paid taxes only if they did business with the government, and all firms commonly reduced their tax bills by underreporting their incomes and employment levels. The government collected some revenues from sales taxes, but these revenues were also a small source of funds.

Iraq used international capital markets to cushion the immediate revenue effects of the Iran-Iraq war. Development programs drawn up during the late 1970s were continued until 1982, financed by borrowed funds. Imports rose by more than 400 percent from 1978 to 1982, mostly because of an increase in non-military goods (Alnasrawi, 1994). By 1990, however, debt service payments were soaking up 55 percent of Iraq's oil revenues (Alnasrawi, 1994). Today, Iraq's debt is estimated to be about $\$ 120$ billion, nearly six times GDP (Alnasrawi, 2002; Taylor 2004).

Effects from the second interruption to Iraq's oil revenues, the UN embargo, could not be papered over with debt. The government then began to finance its operations by printing money. Until then, Iraq had not been a high inflation country. Between 1945 (the first year for which data are available) and 1989, inflation usually stayed in the single digits. But rapid rates of monetary growth after the Gulf War 
caused inflation to rise from 6 percent in 1989 to nearly 500 percent in 1994. The Iraqi dinar depreciated from around 4 dinars per dollar in 1990 to more than 1,700 in 1995.

The rate of inflation exceeded the rate of money growth during this period, as Iraqis fled the dinar as a store of wealth and held gold or foreign currency instead. Because interest rates paid on deposits were capped in the single digits, holding dinars in a bank account was also a losing proposition. One top Coalition budget official surmised that most Iraqis had never seen the inside of a bank when the 2003 war started. More than 85 percent of M1 was held as currency throughout the late 1990s.

\section{Microeconomics and markets}

Because oil is so central to Iraq's economy, understanding Iraq's microeconomic climate in the 1990s begins with understanding the Oil-for-Food program, through which oil revenues flowed from 1996 to 2003. By relaxing the embargo, the program no doubt improved the lives of Iraq's people, particularly its children. But the program adversely affected private economic activity in a number of ways.

Before the Oil-for-Food program, Iraq's food-rationing system supplied only about 1,300 calories per person per day, about 40 percent less than the level recommended by the World Health Organization. The Oil-for-Food program permitted the government to nearly double the average caloric intake in the monthly food ration, to 2,200 calories, by 2002. According to the UN, childhood malnutrition rates dropped by half from 1996 to 2002, while the number of underweight children dropped from 23 percent to 10 percent (United Nations, 2003). The macroeconomic picture brightened as well, as the return of oil revenues reduced the government's need for seignorage revenue. Monetary growth and inflation remained relatively tame in the late 1990s - that is, typically less than 20 percent.

But the Oil-for-Food program reduced incentives for private economic activity. By augmenting the existing rationing system with imported food, the program discouraged the local production and distribution of food and other consumer items. Some agricultural sectors, such as the poultry industry, were helped because they could 
import feed. But small grain farmers experienced extraordinary declines in incomes, because they could not compete with subsidized grain from abroad. Moreover, because the program allotted virtually the same basket to every family, most households sold part of their rations in secondary markets for cash, because they needed different things or because they preferred better quality items. The prices that consumers received in secondary markets were generally less than half the purchase cost of these goods, further depressing prices for local producers. Finally, by distributing food through the government's original food-rationing program, the program maintained the link between each family and their existing food distribution agent, typically a food store or bakery. This discouraged the entry of new retail firms.

\section{Corruption}

The Oil-for-Food program also exacerbated government corruption. After 1999, the UN removed the previous ceiling on permissible oil sales and relaxed the oversight of certain humanitarian imports. Iraq's leaders used the new flexibility to pocket illegal surcharges for oil sales (on the order of 10 percent) and demand kickbacks when purchasing imported goods.

Some elements of Oil-for-Food corruption were known even before the 2003 war. A 2002 report from the General Accounting Office of the United States conservatively estimated that Iraq's government received about $\$ 2.3$ billion in illegal surcharges on oil and commissions on commodity contracts during the preceding five years. This was on top of $\$ 4.3$ billion earned through smuggling oil out of the country (GAO, 2002). Additional details about Oil-for-Food corruption came to light after the war. When preparing budgets of various Ministries in mid-2003, Coalition budget officials were surprised to discover that goods imported through the program would sometimes be awarded to state-owned enterprises (SOEs) for no consideration at all. The SOEs were then free to sell the imported good (a car, for example), with all revenues recorded as "profit," entitling the SOE's managers to hefty bonuses. In March 2004, the GAO upped its estimate of theft through the Oil-for-Food program to $\$ 4.4$ billion. 
Illicit funds earned through the program help explain why Saddam Hussein was able to embark on an ambitious program of palace-building even as many in Iraq struggled to survive. These building programs were no doubt at least partially financed by illicit earnings, but government revenue might also have been used. One government official told us that budget authority for an "irrigation" improvement, for example, might have been used to build a private lake behind one of Saddam Hussein's homes. ${ }^{3}$

In talking with members of Iraq's business community, we were told of another of Saddam Hussein's favored techniques of self-enrichment. He would purportedly encourage the formation of businesses that he believed would become profitable and then nurture their growth through various channels of favored treatment. After a while, Saddam would suddenly close the firm and confiscate its bank accounts and assets, while the owner would "disappear." We were told this was "Saddam's fattening of the lamb before its slaughter."

Corruption extended far below Saddam Hussein's inner circle. Starting a new business required an application to the Ministry of Trade that might take a year to complete. Worse, applications also attracted the attention of other parts of the government, like investigations by the secret police. Applicants were typically investigated to determine whether they had any relatives who belonged to opposition groups, who had deserted or avoided service in the army, or who had belonged to the regional militia in the restive Kurdish part of the country. "Even the involvement of relatives would cause the government to not let the applicant start any kind of business, and may lead to very serious charges," one official said. "That is why not many people would dare start any business"' (Kader Hussein, 2003). One Iraqi auto parts dealer, like other business people, simply avoided registration of his business to escape the attention

\footnotetext{
${ }^{3}$ Coalition advisers also learned to take Central Bank figures with a grain of salt. Under the previous regime, the Bank often used opaque accounting procedures so as to hide transactions, such as transfers of Central Bank of Iraq (CBI) funds to commercial bank accounts controlled by Baath party officials or the transfer of foreign currencies to secret bank accounts abroad. The CBI also masked the real value of transactions in its reports by using the out-of-date official exchange rate, then failing to denote consistently the items that were denominated in foreign currency.
} 
of the government or organized crime. "If you go to the Trade Office, everyone will know," the dealer said. "So one way to keep a low profile is not to register your company. One year after opening my shop, a government inspector came, and I just had to pay him a bribe" (as quoted in Braude, 2003, p. 118).

\section{Iraq's Economy After the War}

After the end of hostilities, the greatest effect of the 2003 war on Iraq's economy was the subsequent decline in oil and electricity production. Oil production had been running at 2.5 million bpd before the war. It dropped to near zero in April; exports ceased until June. Electricity generation fell by about 25 percent, not regaining pre-war levels until October 2003. Based in part on these figures, the International Monetary Fund estimates that GDP fell by about 22 percent in dollar terms for 2003 (IMF, 2003, p. 22).

Both of Iraq's statistical organizations, the CSO and the Central Bank, were heavily looted after the war, and both were slow to recommence operations. As a result, no data measure the effect of the war on private economic activity. It was undoubtedly negative. An August 2003 survey of 393 small firms in Iraq sponsored by the IraqiAmerican Chamber of Commerce revealed that the average size of firms in the survey dropped from slightly more than 16 workers before the war (median size of seven workers) to an average of slightly more than 12 workers (median size of five workers) (Ommar and Khesbak, 2003). Public employment also fell after the war, largely as a result of the Coalition's controversial decision in late May to disband the army. When the war ended, the army consisted of about 500,000 people, or about 7 percent of the current labor force. The Coalition would later pay stipends to former soldiers, but the decision to put them back on the streets without jobs has been blamed for worsening attacks on Coalition forces. In defending this decision, Coalition officials pointed out that much of the army had essentially melted away during the war. They also noted that the army has been a destabilizing political force throughout Iraq's history, dating back to the army's overthrow of the British-installed monarchy in 1958. Another group of public 
employees who lost their jobs were the 15,000-30,000 persons who had belonged to the top four levels of the Baath party. Outside of these changes, government employment levels were generally maintained. In particular, the 500,000 employees at state-owned enterprises continued to be paid after the war, even if electricity shortages, looting, or a lack of demand gave them little to do.

\section{Economic effects of violence}

Street crime has been a serious problem since the war ended. In the late summer of 2003, a World Bank assessment team reported that crime was among the top four obstacles to private-sector investment, along with poor access to finance, telecommunication problems, and macroeconomic instability (UN/World Bank, 2003c). Hassan Fattah, an American journalist of Iraqi descent, started an English-language newspaper in Baghdad soon after the war ended. "What sets Iraq apart from most other nations in transition," Fattah writes, "is the level of risk."

For us, the lesson came early. A day before we published our first issue on $7^{\text {th }}$ July 2003, I woke up with a gun barrel in my face. Seven men were standing over me, holding Kalashnikovs and demanding money. They had nothing against the newspaper; they just saw us as westerners with cash. They tied me up and took our $\$ 12,000$ stash of money (Fattah, 2004a).

Fattah's paper, Iraq Today, shook off this initial setback. By March 2004, it had expanded its initial press run, its online version was reaching thousands of people via the Internet, and the paper's managers were considering a new Arabic edition. But then the paper suspended publication. A mortar round landed outside Iraq Today's office, prompting Fattah to send the staff home for a month while he considered how to deal with the security situation. The paper's financial backers withdrew support in part because of fears of ongoing violence in the country. A close friend and colleague of Fattah's was killed. Fattah himself received enough death threats that he left Iraq in early April, returning the following month to resume publication (Fattah 2004b). 
Despite the difficult commercial environment, a drive around Baghdad reveals large numbers of new shops, manufacturing firms, and even Internet cafes doing business under a skyline laced with construction cranes. One of Iraq's new small businessmen is Nader Hindo, who grew up in Iraq but left the country after he finished high school in 1992. Along with his father (a businessman once jailed by Saddam Hussein), Hindo now runs Neareast Resources, a firm involved in construction, security, information technology, and trade. "Basically," he said, "we have witnessed tremendous growth in our size, staff, and business volume." One way in which Hindo's firm has handled security problems is to break large jobs up into pieces and then try to finish each functional piece of the project in "hours and days rather than weeks or months," he said. "We believe that by reducing the lifetime of a project, you reduce the number of uncertainties that can affect you. Next week there might be protest, an electrical grid shutdown, or your laborers in Sadr City can't get out because there are Coalition roadblocks." Security problems have raised the firm's costs, but markets are clearing. "People who are bold and aggressive are rewarded," Hindo said. "A laborer would cost you $\$ 7$ a day, but if you take him to the Green Zone or hire him during turbulent times, the price goes up by two to three times. With that kind of financial reward, there is always a supply" (Hindo, 2004).

Regional levels of violence are closely correlated with how residents assess Iraq's current economic situation. Figure 3 reports the results of polls commissioned by the CPA and the State Department's Office of Research in early 2004, which asked Iraqis how they viewed Iraq's economy in general and their own family's situation in particular. In Baghdad, 62 percent of respondents said that Iraq's economy is doing better than before the war, with 59 percent viewing their own family's fortunes as improving. Similarly sanguine results were found in Iraq's second largest city, Basra; the northern Kurdish city of Sulamaniyah; and in Babylon. Opinions were far less favorable in the "Sunni Triangle," where most attacks on Coalition forces have taken place. In Tikrit, Saddam Hussein's hometown, only 5 percent of respondents said the country's economy had improved. Views were even worse in nearby Samarra. 
Why the regional discrepancy? No doubt part of it is due to the effect of political violence (as opposed to street crime) on economic activity. Responses probably also vary with local support for the Coalition's presence and the level of government favors that residents enjoyed under the old regime. Even in the Sunni city of Ramadi, though, more than 40 percent of Ramadi residents said that their own family is doing better, even though only 15 percent of these residents said the same for the country as a whole. The pattern of answers to national vs. family-specific questions is reversed in areas where political support for the Coalition is stronger, like Sulamaniyah.

Iraqis remain concerned about the health of the labor market no matter where they live. The first official post-war look at joblessness from the CSO reported an unemployment rate of 28.1 percent for the country as a whole as of October 2003. This rate is about 75 percent higher than the rate recorded in the 1997 census. It is unclear whether unemployment concepts in the two surveys are the same, however, and a separate, private poll taken in February revealed that a plurality of Iraqis think the labor market is better now than before the war (Oxford Research International, 2004). ${ }^{4}$

Whatever the quantitative state of Iraq's labor market, there is widespread agreement that Iraq needs jobs. The February poll also found that 96 percent of Iraqis believed that more employment opportunities would be effective in reducing violence (Oxford Research International, 2004). Today, there is a "chicken-and-egg" relationship between jobs and security. Reductions in crime and violence would undoubtedly improve the employment climate, but these improvements are difficult with a poor job market. One frustrated job seeker from Sadr City (a poor, predominately Sh'ia area of Baghdad) put it this way: "I haven't been working at all for the last two weeks. If I stay like this for another week my family will starve, and if someone comes along with \$50

\footnotetext{
${ }^{4}$ The poll found that 38.9 percent of respondents believed the availability of jobs was either "much" or "somewhat" better than before the war, with 25.3 percent answering that the job situation was much or somewhat worse. The remainder said there had been no change (30.9 percent) or had no answer (4.9 percent).
} 
and asks me to toss a grenade at the Americans, I'll do it with pleasure" (Banerjee and Cushman, 2003).

\section{Coalition Economic Policy}

Although the Coalition Provisional Authority (CPA) enjoyed sweeping powers to make economic policy, policymakers were not free to pull out their textbooks and recast Iraq's economy as they saw fit. They faced three constraints in reforming Iraq's economy: one legal, one political, and one logistical.

Legal authority to reform the country was circumscribed by international treaties. Article 64 of the Geneva Convention of 1949 stipulates that an occupying power can make changes needed "to fulfill its obligations under the present Convention, to maintain orderly government of the territory, and to ensure the security of the Occupying Power." These powers have been liberally interpreted to allow economic reforms that would improve living standards in the occupied country. But there is much less precedent for enacting irreversible reforms that could not be undone by future governments, such as selling off immovable government-owned property. Whether Iraq's state-owned enterprises would fall into this category of assets is open to debate.

The fact that Coalition reforms could be potentially reversed led to the second constraint: the need to gain Iraqi political buy-in on important reform measures. To foster support of reforms, Ambassador Bremer held a series of remarkable Monday night forums with Iraqi business and government leaders in the summer of 2003. Topics discussed included potential reforms to Iraq's agricultural system, whether Iraq should have a tax system (or simply rely on oil revenues to fund the government), how to limit the economic power of former Baathists, how state-owned enterprises should be reformed, and the benefits of foreign investment. These seminars were two-way exchanges of information, with Coalition officials learning crucial institutional details and Iraqis learning about best practices from elsewhere in the world. A formal political constraint on policymaking came when the Iraqi Governing Council was formed on July 13, 2003. The Council's founding agreement called for the CPA to consult with it on all 
major policy changes; in practical terms, this meant that Council approval was a

prerequisite for all important reforms. The Council also appointed new ministers to exercise day-to-day control of ministries starting in September, although senior advisers who worked for the CPA still held final decision-making authority.

The third, logistical constraint facing economic policymakers stemmed from the security situation, which hindered their attempts to learn about Iraq's economy. Almost every workday, advisers donned their helmets and flak jackets for trips to the Central Bank or the Ministry of Finance, riding through Baghdad's crowded streets in SUVs escorted by Army Humvees. But advisers could not take unescorted trips outside the heavily protected Green Zone to talk with shopkeepers about regulation, with workers of state-owned enterprises about potential privatization schemes, or with consumers about potential reforms to the food distribution system. Combined with a lack of official data from Iraq's statistical agencies, advisers often felt that they were navigating the Iraqi economy virtually blind.

\section{Influences on economic policy}

The biggest influence on Coalition economic policy was the experience of the transition economies of Eastern Europe and Central Asia during the 1990s. ${ }^{5}$ Though all

\footnotetext{
${ }^{5}$ The Office of Economic Policy of the Coalition Provisional Authority consisted mostly of employees from national Coalition governments, central banks, and civil affairs units of the Coalition armed forces, an American consulting firm called Bearing Point, Inc., that won a USAID economic reconstruction contract, and private institutions. The staff worked alongside representatives of the World Bank, International Monetary Fund, and United Nations. CPA economists were supported by Treasury employees in Washington assigned to a special task force. Peter McPherson was director of the Office of Economic Policy from May to September 2003. He had served as the director of the U.S. Agency for International Development and as Deputy Treasury Secretary in the 1980s. He later worked in the international banking division of Bank of America before becoming president of Michigan State University in 1993, returning to that position when his time in Iraq ended. McPherson was succeeded on an interim basis by George Wolfe, the U.S. Treasury's Deputy General Counsel. In November 2003, the office came under the direction of Marek Belka, a transition economist from Poland who had served as that country's deputy prime minister and finance minister as well as heading the CPA's international coordination body. Belka left the CPA in May 2004 to become the acting Prime Minister of Poland.
} 
of the economies experienced "transition recessions" in the early years of reform, proper policies helped release resources that were absorbed by the private sector. "With time, if the business environment favors production and innovation rather than rent seeking, restructured and new enterprises gain the critical mass to overcome the negative effects of old enterprises, leading to recovery and economywide growth" (World Bank, 2002, p. xiv).

Iraq, of course, is not Poland. For one thing, direct employment by the government in state-owned enterprises was much smaller in Iraq than in most of the formerly socialist countries. Even more important, most of Iraq's GDP comes from oil. Perhaps the central economic question in Iraq is how oil revenues will be distributed through payments directly to individuals, for example, or by the government through its spending decisions.

Unfortunately, Iraq needs every oil dollar it can get to rebuild its infrastructure. According to World Bank and CPA assessments, Iraq infrastructure investment requirements totaled $\$ 55$ billion immediately after the war. This amount is far in excess of the $\$ 12$ to $\$ 15$ billion Iraq will receive in yearly oil revenues in the near future. As a result, Iraq not only had to ask the international community for help in rebuilding (which it did in an October donors' conference held in Madrid) but must also allocate oil revenues to either running the government or rebuilding the country, not for redistribution from an oil revenue trust fund.

With explicit redistribution schemes on the back burner, economic policy in 2003 focused on installing pro-market reforms that would be maintained by future Iraqi governments. Additionally, Coalition policymakers worked to impose discipline on state-owned enterprises and devise short-term stabilization measures that would be consistent with long-term growth. The two goals of pro-market reform and economic stabilization were central to the first major issue that Coalition economists confronted: What should be done with the Iraqi dinar? 


\section{Currency reform}

Early in the reconstruction, economists worried that the dinar would collapse. Because each dinar featured the image of a smiling Saddam Hussein, fears that the dinar would become worthless once the Coalition took over caused it to weaken to more than 4,000 to the dollar in the spring of 2003. Coalition officials, of course, had no desire to erase the country's dinar-denominated assets. To send a signal that both the dollar and the dinar would be valued in the new Iraq, officials made an explicit decision to pay the April salaries of Iraqi government workers in dinars. These payments were complemented with "emergency payments" made in U.S. dollars. The signal of support for the dinar and the supply of new dollars arriving in the country caused the dinar to strengthen to below 1,500 to the dollar by the end of May. Yet even as a collapse in the dinar was avoided, Iraq's currency situation was disintegrating nonetheless.

Only two denominations of the "Saddam" dinar circulated widely by the end of the war: the 250-dinar note (worth about 17 cents) and a 10,000-dinar note that had been introduced in late 2002 (worth about \$6.50). Immediately after the war, presses, plates, and paper for printing the 10,000-dinar note were stolen from the Central Bank's Dar AlNahrain printing works in Baghdad, leading to fears that the 10,000-dinar note would be widely counterfeited. Additionally, the relatively high value of the 10,000-dinar note made it difficult to use in everyday transactions. For both of these reasons, the larger note traded at a 10 to 30 percent discount relative to the smaller one when the reconstruction began. The discount made the 10,000 unattractive for salary payments and forced Iraqis to carry large wads of 250s when they went shopping. In June, the Coalition decided to print up new 250s to try to meet the demand (complete with Saddam Hussein's picture), but that did little to narrow the discount on the larger bill.

The monetary situation was further complicated by an essentially separate currency in northern Iraq. The Kurdish area continued to use the banknotes that Iraq 
had used before the Gulf War, which were nicknamed "Swiss dinars." 6 Because the Kurdish governorates did not have access to the printing plates for the Swiss dinars and because they refused to follow Saddam's example and print low-quality notes of their own - the supply of Swiss dinars in the north had remained essentially fixed for 13 years. The separate northern currency allowed the region to escape Iraq's ruinous inflation rates of the early 1990s. Yet by 2003, many of the Swiss dinars were falling apart from overuse, held together with tape and staples.

Given this situation, why didn't the Coalition just dollarize the economy, as some observers had suggested (for example, Svejnar, 2003)? Dollarization would have forced Iraq, a major oil exporter, to share the monetary policy of the United States, a major oil importer. It would have also required a massive and expensive airlift of coins to the country, as the Iraqi economy requires several denominations with a lower value than the U.S. one-dollar bill. Perhaps most important, the political symbolism of dollarization would have been disastrous.

Once the decision to create a new, unified currency had been made, economists needed to come up with an acceptable conversion rate between the Swiss dinar in the north and the Saddam dinar in the center and south. The price of a Swiss dinar in terms of the Saddam dinar hovered at about 100:1 from July 1998 to January 2002. But the Swiss dinar appreciated steadily throughout 2002, and the Saddam dinar depreciated in the run-up to the war. By January 2003 the exchange rate was about 300:1, falling to about 250:1 by mid-2003. A comparison of prices in the two regions of the country indicated that a 250:1 rate was far out of line with purchasing power parity. The PPP rate appeared much closer to the 100:1 exchange rate that had prevailed from 1998 to 2002. After extensive discussions that included Iraqi leaders in both parts of the country, the Coalition Provisional Authority decided to set the conversion rate at one Swiss dinar

\footnotetext{
${ }^{6}$ The origin of the "Swiss Dinar" term is murky. (Even the acting Minister of Finance did not know where the name came from.) One possibility is that the name derives from the fact that the plates for this currency were made in Switzerland (though most bills were actually printed in England). Another rumored possibility is that because Iraq did not have a history of inflation before the Gulf War, people thought the Iraqi dinar was "as solid as a Swiss franc."
} 
to 150 Saddam dinars - essentially a compromise between the PPP rate and the market rate.

One way to bring about a "new" currency would have been to print up new Swiss dinars and distribute them around the country. This plan would have absolved the Coalition from making the tricky political decision of what - or who - should appear on the faces of the new banknotes. But spreading the Swiss dinar would have meant that the center and south - home of more than 80 percent of the population - would have had to change their prices and wages. The solution came when a visiting currency expert pointed out that the technology existed to change the denominations on the Swiss dinar plates without affecting the designs on their faces. Existing Swiss plates could thus be modified to create higher-denomination dinars that would be in line with the price level in most of the country. The new dinars could then be exchanged at a one-to-one rate with the Saddam dinar. To prevent confusion with existing Swiss dinars, the new dinars would also be printed in different colors. Anti-counterfeiting measures would also be included.

Figure 4 shows the exchange rates for the Saddam dinar in mid-2003. On May 5 (the earliest date for which official daily data are available), the exchange rate for the 250 stood at about 2,000 to the dollar, while the rate for the 10,000 stood at more than 2,500. The 250/10,000 gap fluctuated between 15 and 35 percent following the July 7 announcement of the impending banknote exchange. The gap finally closed in the first week of September, a few weeks before the start of the currency exchange, when both denominations traded near 2,100 to the dollar. The dinar has since strengthened to about 1,450 to the dollar.

On October 15, 2003, the currency exchange for new dinars began. The massive movements of currency around the country went off well, although two currency convoys were unsuccessfully attacked in an intense firefight near Samarra in late November. By the time the currency exchange ended three months later, a pound of old currency had been turned in for every man, woman, and child in the country. 


\section{Reopening banks and encouraging lending}

Although some private banks exist, Iraq's banking system is dominated by the two state-owned banks, Rafidain and Rasheed. Taken together, in 2003 these two banks held about 90 percent of total banking sector assets (about $\$ 2$ billion) and operated 340 branches around the country. Each of these branches was a tempting target to postwar looters. Some bank managers displayed great bravery in the days following the war, saving the assets and records of their banks from being stolen or destroyed. Most vaults were not breached by looters, though doors were damaged and building interiors were trashed. ${ }^{7}$ Reopening bank branches presented financial and logistical challenges, such as organizing a military escort for currency movements to a re-opened bank. Despite these challenges, most bank branches had been reopened by the end of the summer.

The CPA took two major steps in 2003 intended to strengthen Iraq's banking industry over the long run. In November, the Trade Bank of Iraq was begun to facilitate large international transactions. In late September, the CPA and the Governing Council issued a 66-page commercial bank law that followed international best practices, covering virtually all aspects of banking operations. The order requires that the country's private banks have paid-in capital of at least 10 billion dinars (around $\$ 5$ million at that point), though the country's 17 existing private banks were given 18 months to reach that amount. The bank law also allows six foreign banks to have majority owned subsidiaries or to establish branches in Iraq during the next five years, and allows an unlimited number of foreign banks to buy up to 50 percent of an existing Iraqi bank. Other financial reforms include establishment of the "micro-lending" credit facilities around the country and the liberalization of interest rates, which took place on March 1, 2004.

\footnotetext{
${ }^{7}$ One example is the Central Bank itself, where looters attempted to blow open the vaults. Perhaps unbeknownst to them, the vaults had held a priceless collection of ancient jewelry, the Treasures of Nimrud. Fortunately, the doors held, though the Central Bank building itself was gutted and burned in the immediate postwar chaos.
} 


\section{International openness}

After more than a decade of international sanctions and limited trade, Iraqis were starved for imports. Soon after entering Baghdad, American officials announced that Iraq's borders were open, and on June 8, 2003, the CPA formalized a "tariff holiday" that eliminated virtually all barriers to trade until December 31, 2003. Imports poured into Iraq's stores, street markets, and roadside stands. Demand was especially strong for goods that had been prohibited by the previous regime, such as satellite dishes.

The tariff holiday was never intended to be permanent. On September 19, 2003, the CPA issued an Order calling for a uniform 5 percent "reconstruction surcharge" to be levied on imports into the country, excluding food, medicine, clothing, and books. Some advisers would have preferred a zero surcharge, while other advisers argued that the distortionary effects of a small, uniform tariff were justified given the desire for government revenues. After some rescheduling (to allow a collection system to be set up), the levy was ultimately scheduled to go into effect on April 1, 2004. The levy is set to end on January 1, 2006.

Encouraging Iraqis to embrace an open foreign-investment regime was also a Coalition priority. Iraq's previous government had barred investment from non-Arab countries. After the war, many Iraqis feared that allowing better-funded and more productive foreign firms into Iraq would destroy domestic businesses. Economists from the Coalition and from international financial institutions responded to these concerns with three arguments. First, they noted that Iraq was starved for capital. If foreigners could supply some of the capital that Iraq needed, so much the better. Second, they argued that foreign investment would dilute the power of rich domestic investors who had amassed their fortunes through corrupt connections with the previous regime. Third, they cited studies and presented data showing that in other countries, foreign investment has been a prime source of technology transfer and downstream demand for domestically produced goods. 
After some debate, the Governing Council endorsed this view. In September 2003, Iraqi Finance Minister Kamel al-Gailani announced a new foreign investment law designed to treat all foreign investors the same as domestic ones. The new law allows foreign investors to own 100 percent of businesses outside of the natural resource industries like the oil sector. All after-tax profits can be repatriated. In addition to the bar against foreign oil investment, the law requires that foreign retailers post a $\$ 100,000$ bond and prohibits foreigners from purchasing land, which can nevertheless be leased for up to 40 years. In February 2004, Iraq was granted observer status at the World Trade Organization.

\section{Fiscal and monetary policy}

Iraq's oil wealth means that it does not have to levy domestic taxes. Arguments for the exclusive use of oil revenues to fund the government include the distortions that arise from any proportional tax and the costs of administering a tax system. In Iraq's case, the stimulus to business of a no-tax regime might be especially valuable, because Iraq's exports of natural resources may put upward pressure on its real exchange rate and thereby limit non-energy exports (the so-called "Dutch disease"). Yet a tax system would allow Iraqis to experience directly the opportunity cost of government spending. It would also send a message to international donors that Iraqis are bearing part of the cost of their own reconstruction.

In September, the Coalition announced that all taxes for 2003 were suspended, but that taxes would be imposed for future years. The final tax strategy calls for individual taxes to be assessed on a progressive basis beginning April 1, 2004, with the top individual rate of 15 percent kicking in at incomes of about $\$ 700$ per year. Business income is to be taxed at a flat rate of 15 percent.

Oil exports also influence Iraq's monetary policy, because two-thirds of Iraq's economic output is received by selling oil to international markets for a price denominated in U.S. dollars. Hence, monetary policy is closely intertwined with the exchange rate and how these U.S. dollars are converted to dinars. Early on, Coalition 
advisers considered an exchange rate regime involving a hard peg to the U.S. dollar (or other foreign currency) to provide the economy with a transparent nominal anchor. ${ }^{8}$ Ultimately, Iraq has adopted a de facto managed float instead. A floating exchange rate allows Iraq's economy some cushion for oil-price shocks, since a drop in the oil price is likely to cause the dinar to fall. This would encourage Iraq's as-yet-limited non-oil exports to rise and increase demand for its import-competing industries.

Central banks in small open economies typically intervene in currency markets to limit extreme volatility. Currently, the tool used by the Central Bank of Iraq to influence the exchange rate and control the growth of the domestic monetary base is a foreign exchange auction, which has occurred on a daily basis since October. The Ministry of Finance sells dollars from its oil receipts to the CBI, purchasing dinars to pay for government operations. The CBI then sells some of those dollars in the daily foreign exchange auctions. Transactions at this auction were typically $\$ 10-\$ 15$ million a day by the end of March 2004.

As of mid-2004, Iraq is effectively a dual-currency economy, in which major consumer purchases are priced and paid for in dollars. Although dinars are preferred for small-scale transactions, dollars are readily accepted. Consequently, fluctuations in the exchange rate have an immediate impact on the money supply, real and nominal, as denominated in a combination of dollars or dinars. In the future, the Central Bank will be able to undertake open market operations, trading existing Ministry of Finance securities. For the immediate future, however, the

\footnotetext{
${ }^{8}$ In particular, a currency board arrangement would have required that the Central Bank of Iraq issue new currency only when the bills were fully backed with foreign exchange reserves. But this approach had practical difficulties. It was difficult to know the correct parity between the dinar and the dollar. Additionally, central banks can circumvent a currency board through official borrowing of foreign currency from abroad. Finally, had Iraq been required to fully back its currency with dollar-denominated assets, it would have been forced to purchase from $\$ 2-\$ 4$ billion of financial securities that would have been better invested in Iraq's infrastructure. Once a currency board was ruled out, a hard exchange rate peg without full backing was ruled out as well, since it seemed likely to encourage speculators to test the peg by selling dinars for dollars until the central bank had drained its foreign exchange reserves and was forced to break the peg.
} 
foreign exchange auction is likely to remain the CBI's primary monetary policy tool.

In the long run, the credibility and independence of the CBI will be vital no matter what its specific monetary instruments. In March 2004, the CPA and Governing Council adopted a Central Bank law that incorporates global best practices. Central to the law is the statement that "[t]he primary objectives of the CBI shall be to achieve and maintain domestic price stability and to foster and maintain a stable and competitive market-based financial system. Subject to these objectives, the CBI shall also promote sustainable growth, employment, and prosperity in Iraq."

\section{Legal reform}

Over time, Iraq's commercial laws were corrupted by the inclusion of socialist objectives or imperfect enforcement of the laws by the former regime. On April 1, 2004, the Coalition and Governing Council issued an amended version of the Companies Law of 1997, streamlining registration procedures for private firms (so they can be completed in a month or less) and removing the ability of government planners to control private business decisions. Work was also underway on reforming Iraq's bankruptcy, labor, and secured transactions laws. By March 2004, the Coalition had also vetted 80 percent of Iraq's judges, removing 25 percent and hiring an additional 130. A Commission on Public Integrity had been formed, and Inspector Generals were planned for each government ministry.

\section{Reforms Left for Future Iraqi Governments}

As of early April 2004, most economic reforms that had been enacted did not entail much short-term sacrifice on the part of Iraqis. Iraqis were generally glad to get a new currency. They were not immediately affected by new banking or commercial laws, nor had the infrastructure for tax collection yet been put in place. But achieving maximal rates of per-capita income growth in the long run will require some short-term sacrifices. This section discusses two reforms that were left undone by the Coalition for fear of 
worsening unrest in the country. It concludes with a third that was omitted for fear that there was no margin for error in case it went wrong.

\section{State-owned enterprises}

Reform of Iraq's state-owned enterprises still has far to go. In 2003, the Coalition prevented the SOEs from accessing their bank accounts and limited any SOE subsidies to formal budget items, in contrast with the past convention of providing implicit subsidies via below-market exchange rates or other surreptitious accounting conventions. The Coalition also erased all inter-SOE debts as of the end of the war. This was done in order to get the SOEs to focus on becoming productive in the future and to avoid wasting resources on collecting debts incurred by other SOEs in the past.

Originally, the Coalition intended to pay the salaries of SOE workers only through the end of 2003, but Iraqi opposition to a salary cutoff caused payments to be extended into 2004

The Coalition has begun taking applications from investors interesting in leasing some large SOEs, a possible first step to privatizing them under a future Iraqi government. SOEs have also entered into joint ventures with foreign firms, including a deal that a construction SOE signed with a Saudi firm. Yet many SOEs will have to be closed, including the sugar refinery in Sulamaniyah that was destroyed in the Iran-Iraq war but which never laid off its workforce. An optimal way to close SOEs would be to give each unemployed worker a large severance payment. Such a payment would not only cushion the blow of losing a job, but would also give the worker some seed money to start his own business should he so desire.

\section{Raising energy prices}

Energy prices in Iraq are far too low. Because of government subsidies, the price of premium grade gasoline is 50 dinars (or 3.2 cents) per liter, compared with more than $\$ 1$ per liter in Turkey, \$0.42 in Jordan and \$0.50 in Syria. Much of the benefit from Iraq's oil subsidies flows to illegal exporters and black-market resellers, who profit from the 
discrepancy in prices. Other forms of energy, such as electricity and liquid propane gas, are also heavily subsidized. The total opportunity cost of the provision of oil products at government-established prices is about $\$ 4.9$ billion per year - equivalent to more than a third of the 2004 budget. $^{9}$

Liberalizing energy prices is bound to be controversial. But the experiences of other countries shows that political unrest is minimized by announcing the program far ahead of time and by ensuring that market demand is met by true liberalization (so that the program is not seen merely as justification for an arbitrary price hike). Unrest is also reduced when it is clear to households that the policy will not be rescinded and when prices are increased in a time of economic upswing, rather than in a downturn.

\section{Replacing food rations with a cash payment or "oil dividend"}

One potential reform would improve Iraq's microeconomic climate while establishing a precedent for the distribution of oil revenues at the same time. The government's food ration system, now funded by oil sales, could be turned into a monthly allocation of cash. The funds would then provide a source of demand for Iraq's private sector, expand the consumption set of Iraqis, and establish the crucial precedent that Iraq's oil wealth belongs to its people and not to the government. To ensure stability, the program could be phased in geographically, neighborhood by neighborhood, after a series of trials.

While most economists were excited about the possibility of monetization, many Iraqis felt that the country had enough on its plate in 2003 and 2004. Undertaking such a massive reform might be destabilizing if people worried that the private sector could not

\footnotetext{
${ }^{9}$ Exacerbating the costs of the oil product subsidies are their distortionary effects. The U.S. government appropriated $\$ 690$ million to assist Iraqis in buying kerosene and other refined oil products, but Iraqi "demand" for these products at the subsidized prices still could not be satisfied. Moreover, investment funds are being misallocated as Iraqi households purchase diesel generators and air conditioners that will become uneconomical when fuel prices rise to reflect true costs. Finally, the bulk of the subsidies go to the rich, who own more cars, have larger homes, and consume more electricity than the poor.
} 
respond quickly enough to meet the country's food needs. Yet given the benefits of monetization, it is likely that future governments will consider it seriously.

\section{Conclusion: Iraq's Economic Prospects}

The year 2004 should see a sharp economic expansion in Iraq. In addition to private-sector growth, employment driven by public spending is rising, with the Coalition having created about 380,000 jobs directly as of early March. About 220,000 of these jobs were in security or national defense, with another 68,000 persons working as civilian contractors on Coalition projects and the remainder in regional jobs programs or military support.

The International Monetary Fund estimates that GDP should grow almost 30 percent in dollar terms this year, owing in large part to reconstruction expenditures. The United States, for example, plans to allocate $\$ 10$ billion of the $\$ 18.4$ billion in reconstruction expenditures it appropriated in late 2003. About 40 percent of these funds should be spent in Iraq. Reconstruction expenditures will also be financed by Iraq's own budget, which remains extraordinarily reliant on oil revenues: More than 95 percent of government revenues in 2005 and 2006 are to come from the oil sector. Thus, Iraq's budget is highly vulnerable both to the risk of sabotage of oil production and also to fluctuations in the world market price of oil. Iraq will not have to pay down its foreign debt until 2005 at the earliest. Several large creditors have agreed to "substantial" debt reductions, though details have yet to be worked out.

In the long run, economic growth in Iraq will depend on fostering private-sector growth outside the oil sector. This, in turn, will hinge on whether the future political system maintains the pro-market outlook of Coalition policy. Whether Iraqis are willing to look to the private sector for jobs and prosperity - rather than to the government that has literally fed them for years - is an open question. One of the most disheartening pieces of economic information to emerge from Iraq in 2004 was contained in a poll commissioned by the International Republican Institute in December 2004. The poll asked Iraqis what positions they would find most appealing in a political party. Results 
are graphed in Figure 5. By far the most popular position was "more government jobs," which was endorsed by 49 percent of Iraqis. By contrast, only 5 percent of Iraqis supported "more private sector jobs." Part of the support for government employment may reflect a desire for stability amid the massive changes going on in the economy. But support may also result from the government's traditional role at the center of Iraq's economic life.

Countering the inertial obstacles to market reform in Iraq will be the large group of Iraqis who have embraced market opportunities in the past 18 months - importing goods for sale, opening new firms, seeking out customers for their banks and foreign partners for joint ventures. Iraqi exiles are also returning to the country, no doubt driven by the desire to help their country rebuild while making money at the same time. Given these opposing forces, it is impossible to predict the future direction of Iraqi economic policy. The only certainty was voiced by Ambassador Bremer in his speech in Amman more than a year ago: "Just as forming a vibrant political climate in Iraq will entail many challenges, so too creating a vibrant economy in Iraq will not be easy." 


\section{References}

Alnasrawi, Abbas (1994). The Economy of Iraq: Oil, Wars, Destruction of Development and Prospects, 1950-2010. Westport, CT: Greenwood Press. (2002). Iraq's Burdens: Oil, Sanctions and Underdevelopment. Westport, CT: Greenwood Press.

Banerjee, Neela and John H. Cushman Jr. (2003). “Unemployed Iraqis Say New Jobs will Pay Off in Greater Security for All," New York Times, February 8.

Braude, Joseph (2003). The New Iraq: Rebuilding the Country for Its People, the Middle East, and the World. New York, NY: Basic Books.

Fattah, Hassan (2004a). "Occupation Reporter: Iraq Today's Story," Prospect Magazine, March. Also available at http://www.hassanfattah.com.

Fattah, Hassan (2004b). E-mail interview.

General Accounting Office (2002). “Weapons of Mass Destruction: UN Confronts Significant Challenges in Implementing Sanctions Against Iraq," May, Report GAO-02-625. Washington, D.C.

Available at http://www.gao.gov/new.items/d02625.pdf.

Hindo, Nader (2004). E-mail interview.

International Monetary Fund (2003). “Iraq: Macroeconomic Assessment," October. Available at http://www.imf.org/external/np/oth/102103.pdf.

Kader Hussein, Tania (Assistant to the Prime Minister, Kurdish Regional Government) (2003). E-mail interview, December.

Oliver, Dave and Peter McPherson (2003). "Restarting the Economy of Iraq." Unpublished manuscript.

Ommar, Raad and Sabah Khesbak (2003). “Conditions and Expectations for Private Enterprise in Iraq: Findings from a Survey of Iraq's Small and Medium Sized Business Owners and Managers," Iraqi-American Chamber of Commerce and Industry. Available at http://www.cipe.org/pdf/iraq survey final.pdf.

Oxford Research International (2004) National Survey of Iraq: February 2004. Available at http://news.bbc.co.uk/nol/shared/bsp/hi/pdfs/15 03 04 iraqsurvey.pdf. 
Svejnar, Jan (2003) "A Strategy for the Economic Reconstruction and Development of Iraq," University of Michigan mimeo. Available at: www.wdi.bus.umich.edu/events/Post-War_Iraq_policy_paper.doc.

Taylor, John B. (2004). "Financial Reconstruction in Iraq," testimony before the Senate Banking, Housing, and Urban Affairs Committee, February 11. Available at http://www.ustreas.gov/press/releases/js1165.htm.

United Nations (2003), Oil-for-Food Fact Sheet, available at http://www.un.org/Depts/oip/background/fact-sheet.html.

United Nations/World Bank (2003a), Joint Iraq Needs Assessment: Electricity. Available at http://nweb18.worldbank.org/mna/mena.nsf/.

United Nations/World Bank (2003b), Joint Iraq Needs Assessment: Education. Available at http://nweb18.worldbank.org/mna/mena.nsf/.

United Nations/World Bank (2003c), Joint Iraq Needs Assessment: Investment Climate. Available at http://lnweb18.worldbank.org/mna/mena.nsf.

World Bank (2002). Transition: The First Ten Years. Washington, D.C.: World Bank.

World Bank (2003). World Bank Data Sheet for Iraq. Available at http://lnweb18.worldbank.org/mna/mena.nsf/Attachments/Datasheet/\$File/iraqpro totype.pdf. 
Figure 1: Per Capita GDP in Iraq (1968-2001)

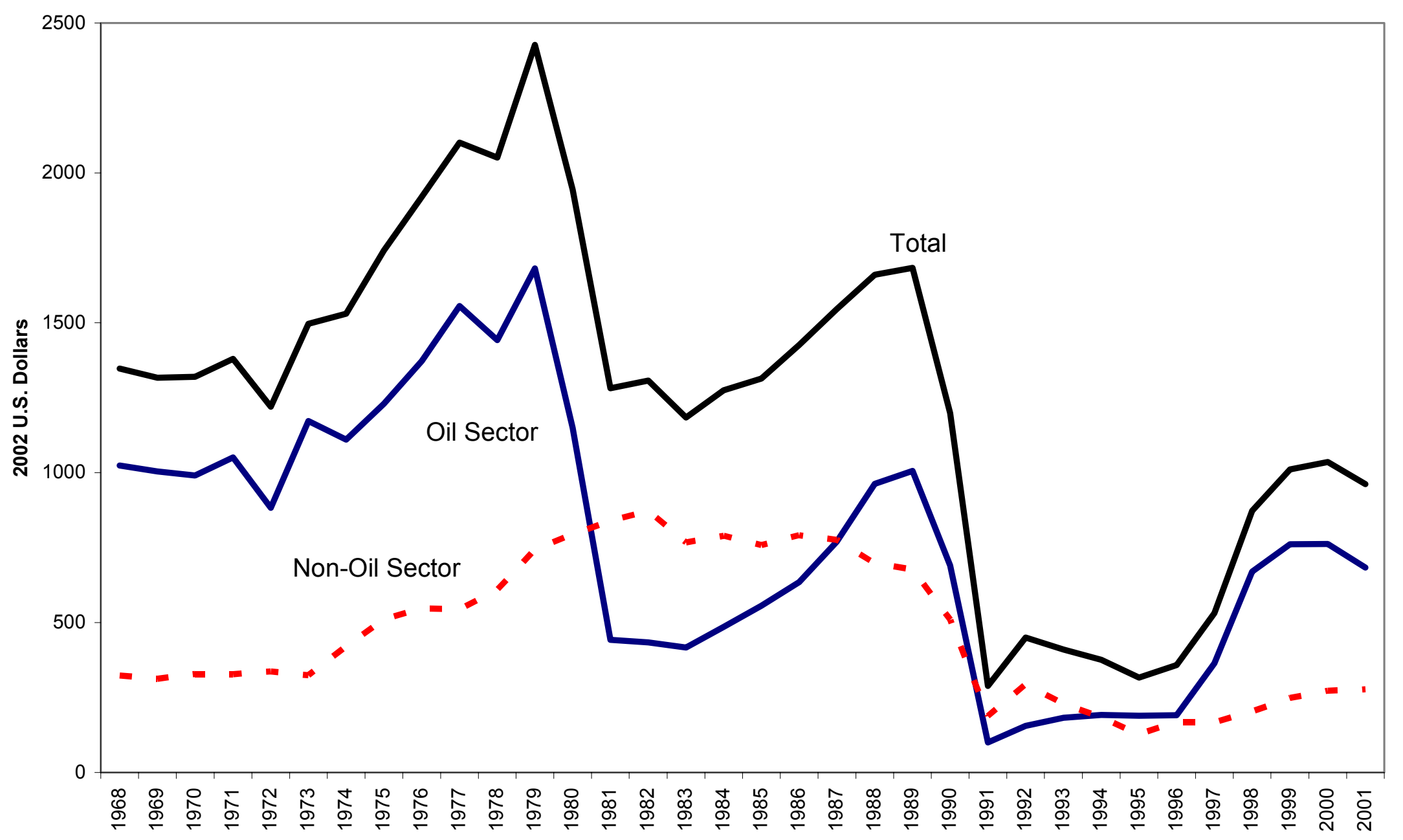

Source: Authors' calculations using data from the Central Statistical Office, Iraqi Ministry of Planning; and U.S. Department of Energy 
Table 1: Labor Market Data from the 1997 Census

Men

Women

Civilian Labor Force as Percentage of Population Aged 10+

66.8

7.5

Shares of Civilian Labor Force Employed in:

Public Administration

Wholesale and Retail Trade

19.3

Agriculture

Manufacturing

Education

Mining and Quarrying

Other

4.3

2.6

0.6

16.9

17.9

4.5

24.1

6.4

37.4

0.7

Share of Civilian Labor Force Unemployed

15.9

Source: 2002 Annual Abstract of Statistics, Ministry of Planning 
Figure 2: Gross Capital Formation (1980-2001)

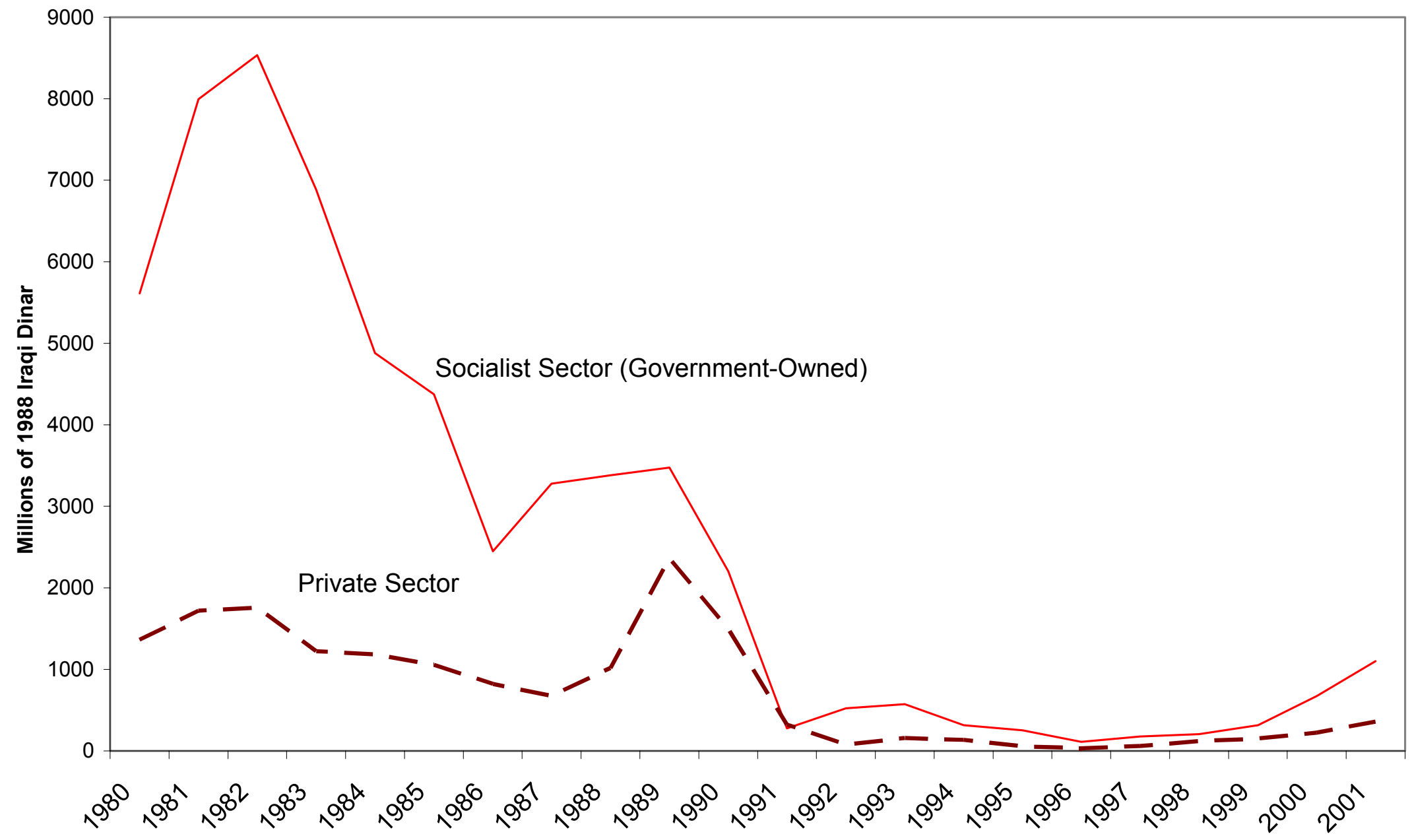

Source: Central Statistical Office, Iraqi Ministry of Planning 
Figure 3:

Fractions of Poll Respondents Reporting Economic Improvement for Iraq as a Whole (1st \%) and for Respondent's Own Family (2nd \%)

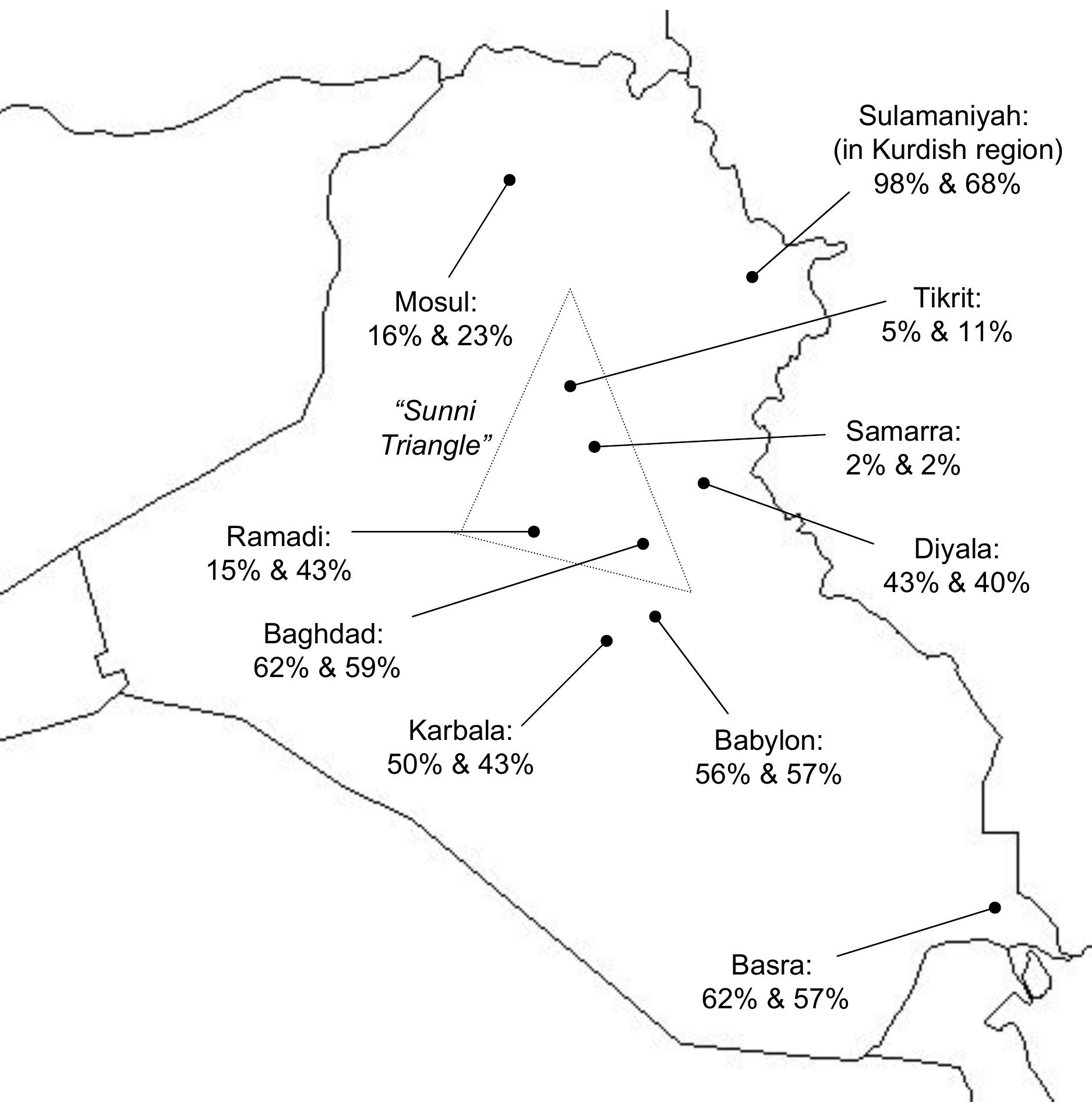

Source: Early 2004 polls sponsored by the Coalition Provisional Authority and the Office of Research, US. Department of State. Data for Karbala, Tikrit, and Samarra are from a Jan 2004 poll. Data from all other cities are from a Feb 2004 poll. 
Figure 4: Exchange Rates for the Iraqi Dinar

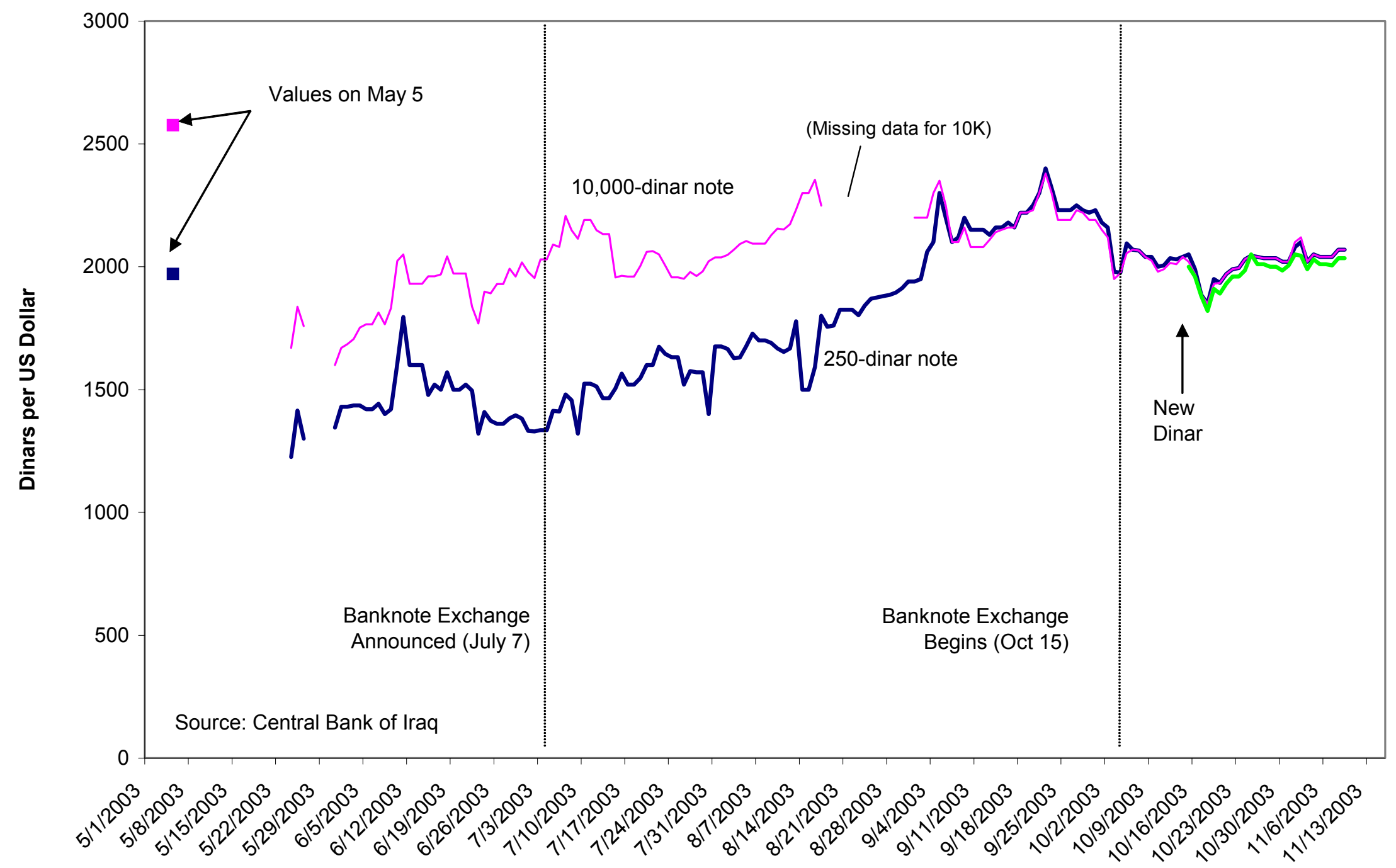




\section{Figure 5: Political Attitudes of Iraqis}

"I would be more likely to support a party that advocated or promised ... "

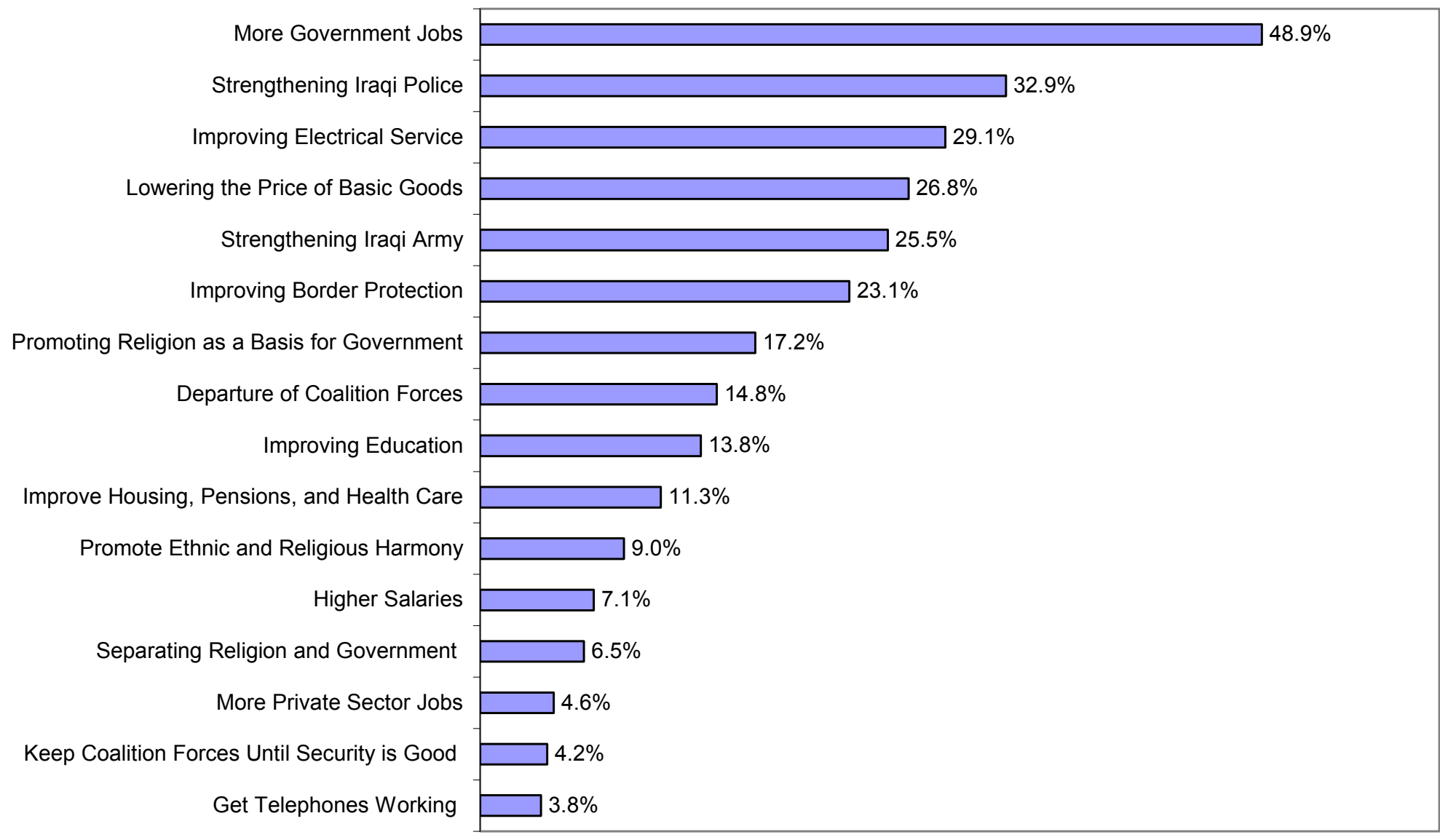

Source: December 2003 poll of 1,531 Iraqis sponsored by the International Republican Institute. 